\title{
Agata Jakubowska
}

Uniwersytet Ekonomiczny w Katowicach

e-mail: agata.jakubowska@ue.katowice.pl

\section{PRZEMIANY INSTYTUCJONALNE NA RYNKU FINANSOWYM W POLSCE - WYBRANE ASPEKTY INSTITUTIONAL CHANGES ON THE FINANCIAL MARKET IN POLAND - SELECTED ASPECTS}

DOI: $10.15611 /$ pn.2017.488.05

JEL Classification: F55, O17

Streszczenie: Rozpoczęta w roku 1989 transformacja systemowa w Polsce doprowadziła do przemian zarówno instytucji formalnych, jak i nieformalnych we wszystkich obszarach gospodarki. Jednym z obszarów przemian w tym okresie był rynek usług finansowych i związane z nim instytucje. Banki i cały system bankowy z uwagi na swoją rolę w gospodarce zostały poddane przemianom w pierwszej kolejności. Rozpoczęte reformy instytucji formalnych doprowadzić miały do powstania nowego konkurencyjnego sektora bankowego. Przemiany nastąpiły zarówno w obszarze instytucji formalnych, jakimi były ustawowe normy i zasady regulujące reguły gry na rynku finansowym, jak i w obszarze instytucji nieformalnych, czyli np. zaufania do instytucji bankowych i całego systemu bankowego. Celem artykułu jest próba pokazania, w jaki sposób zmieniały się instytucje formalne i nieformalne rynku finansowego w Polsce po roku 1989.

Słowa kluczowe: przemiany instytucjonalne, instytucje formalne, instytucje nieformalne, rynek usług finansowych.

Summary: System transformation which began in 1989 in Poland caused some changes in formal and informal institutions in all economic areas. One of those areas was financial market and institutions which were connected with that market. Banks and the whole banking system were transformed at first. The reforms of formal institutions were supposed to bring new, more competitive banking sector. The changes were noticed in formal institutions like legal rules on the financial market and informel institutions like trust to bank's institutions and the whole banking system. The main purpose of this article is to present how formal and informal institutions have been changed on the financial market in Poland after 1989.

Keywords: institutional changes, formal institutions, informal institutions, financial services market. 


\section{Wstęp}

W Polsce po roku 1989, w okresie transformacji ustrojowej i gospodarczej, obserwować można było przemiany zarówno instytucjonalne, jak i gospodarcze. Przemiany te dotyczyły wszystkich obszarów gospodarki, w tym także rynku usług finansowych. Podmioty funkcjonujące na tym rynku, a szczególnie instytucje bankowe, miały ogromne znaczenie i wpływ na rozwój gospodarczy państwa. $Z$ tego też powodu konieczne były zmiany instytucjonalne w tym obszarze. Jeśli mówimy o zmianach instytucjonalnych, to mamy na myśli zmianę zarówno instytucji formalnych, jak i nieformalnych. Dalsze rozważania skupią się na przemianach instytucjonalnych sektora bankowego w Polsce po roku 1989. Celem artykułu jest próba pokazania, w jaki sposób zmieniły się instytucje formalne i nieformalne rynku finansowego w Polsce po roku 1989.

\section{Instytucje formalne i nieformalne - ujęcie teoretyczne}

Instytucje mogą być rozumiane i utożsamiane z organizacją, ale także jako różnego rodzaju reguły gry w społeczeństwie, wypracowane ograniczenia o charakterze formalnym i nieformalnym, normy i zasady postępowania, trwałe systemy ustalonych i wdrożonych reguł społecznych. W niniejszym opracowaniu podstawą rozważań są instytucje, które „organizują, sterują i kształtują procesy gospodarcze” [Kołodko 2004, s. 42]. Według tego autora instytucjami są zatem:

1. „... Legalne i zwyczajowo akceptowane w praktyce procedury i zasady postępowania.

2. ... Obowiązujące prawo i przepisy, które zostały stworzone w celu ochrony interesów podmiotów funkcjonujących na rynku.

3. ... Organizacje oraz struktury administracyjne i polityczne obsługujące podmioty działające na rynku ....

4. ... Zaliczyć także wypada kulturę i mentalność rynkową ..." [Kołodko 2004, s. 43].

Pojęcie „,instytucja” definiowane jest w różny sposób, tab. 1 przedstawia tylko wybrane definicje tego pojęcia.

W zależności od przyjętego kryterium instytucje mogą być klasyfikowane w różny sposób (szerzej [Jakubowska, Grabowska-Powaga 2016, s. 402-404]):

- Stopień sformalizowania: instytucje formalne i nieformalne.

- Poziom hierarchii: poziom 1: instytucje nieformalne; poziom 2: otoczenie instytucjonalne; poziom 3: zarządzanie - działanie gry, przestrzeganie reguł gry, regulacja struktury zarządzania transakcjami; poziom 4: alokacja zasobów i zatrudnienia.

- Obszar działania: instytucje gospodarcze, polityczne, prawne, społeczne (por. [Jütting 2003, s. 11-14; Williamson 2000, s. 597-598]). 
Tabela 1. Wybrane definicje pojęcia instytucja

\begin{tabular}{|c|c|}
\hline Autor & Definicja \\
\hline $\begin{array}{l}\text { T. Veblen } \\
(1857-1929)\end{array}$ & $\begin{array}{l}\text { „... Instytucje społeczne to w swej istocie dominujące sposoby myślenia, uwzględ- } \\
\text { niające poszczególne warunki społeczne, poszczególne funkcje jednostki i społecz- } \\
\text { ności. [...] Instytucje społeczne - czyli nawyki myślowe czy sposoby ujmowania } \\
\text { zjawisk ...” [Veblen } 2008, \text { s. } 161]\end{array}$ \\
\hline $\begin{array}{l}\text { W. Mitchell } \\
\text { (1874-1948) }\end{array}$ & $\begin{array}{l}\text { „Instytucje to powszechne zwyczaje postępowania ludzi. W gospodarce realizują oni } \\
\text { swe własne cele, posiadając wolę i świadomość, a więc w pewnym stopniu niezależ- } \\
\text { ność od otaczającego ich świata. Instytucje pojmowane jako powszechne zwyczaje } \\
\text { istniejące w sferze gospodarki, mają charakter socjologiczny” [Spychalski 1999, } \\
\text { s. 342] }\end{array}$ \\
\hline $\begin{array}{l}\text { J.R. } \\
\text { Commons } \\
(1862-1945)\end{array}$ & $\begin{array}{l}\text { „.... możemy definiować instytucję jako działanie zbiorowe w celu kontroli działań } \\
\text { indywidualnych. Działania zbiorowe obejmują wszystko od niezorganizowanych } \\
\text { zwyczajów po wiele zorganizowanych i dobrze funkcjonujących organizacji, takich } \\
\text { jak rodzina, przedsiębiorstwo, [...] związki zawodowe, system rezerw federalnych, } \\
{[\ldots] \text { państwo [...]. Działanie zbiorowe jest nawet bardziej uniwersalne w niezorga- }} \\
\text { nizowanej formie zwyczaju niż w zorganizowanej formie przedsiębiorstw. Jednak } \\
\text { nawet dobrze funkcjonująca organizacja jest również zwyczajem” [Commons 1934, } \\
\text { s. } 69-70,72 \text { ) }\end{array}$ \\
\hline $\begin{array}{l}\text { G.M. } \\
\text { Hodgson } \\
(1946) \\
\end{array}$ & $\begin{array}{l}\text { "Instytucje to trwałe systemy ustalonych i wdrożonych reguł społecznych, które } \\
\text { strukturyzują społeczne interakcje” [Hodgson 2006, s. 18] }\end{array}$ \\
\hline $\begin{array}{l}\text { D.C. North } \\
(1920-2015)\end{array}$ & $\begin{array}{l}\text { „Instytucje są regułami gry w społeczeństwie lub, bardziej formalnie, są one obmy- } \\
\text { ślonymi przez ludzi ograniczeniami, które kształtują ich wzajemne oddziaływanie na } \\
\text { siebie” [North 1990, s. 3] } \\
\text { „Instytucje są to ograniczenia, wypracowane z wykorzystaniem wszystkiego, co } \\
\text { jest w ludzkiej mocy, które kształtują strukturę współdziałania ludzi. Obejmują one } \\
\text { ograniczenia formalne (np. reguły, prawa, konstytucje), nieformalne (np. normy } \\
\text { zachowań, konwencje, dobrowolne kodeksy zachowań) oraz charakterystyki ich } \\
\text { wdrażania ...” [North 1994] }\end{array}$ \\
\hline
\end{tabular}

Źródło: opracowanie własne na podstawie [Veblen 2008; Spychalski 1999; Commons 1934; Hodgson 2006; North 1990; 1994]

Do dalszych rozważań nad instytucjami w niniejszym artykule przyjmuje się pierwszy podział instytucji na formalne i nieformalne zaproponowany przez D.C. Northa. W roku 1990 w swojej publikacji Institutions, Institutional Change and Economic Perfomance [North 1990, s. 3] napisał on, że „Instytucje są regułami gry w społeczeństwie lub, bardziej formalnie, są one obmyślonymi przez ludzi ograniczeniami, które kształtują ich wzajemne oddziaływanie na siebie”. W roku 1994 doprecyzował on swoją wizję instytucji, pisząc, że „Instytucje są to ograniczenia, wypracowane z wykorzystaniem wszystkiego, co jest w ludzkiej mocy, które kształtują strukturę współdziałania ludzi. Obejmują one ograniczenia formalne (np. reguły, prawa, konstytucje), nieformalne (np. normy zachowań, konwencje, dobrowolne ko- 
deksy zachowań) oraz charakterystyki ich wdrażania. Łącznie określają one strukturę bodźców we wspólnotach, a zwłaszcza w gospodarkach" [North 1994, s. 360]. Instytucje formalne, czyli takie jak np. prawo, normy, konstytucje, są tworzone w sposób świadomy i celowy, a ich twórcami są najczęściej władze polityczne. Instytucje nieformalne, do których zalicza się najczęściej różnego rodzaju normy, reguły postępowania, obyczaje, tradycje czy zaufanie, powstają w sposób spontaniczny, ewolucyjny (por. [Wilkin 2016, s. 147-149]), a „twórcami” ich jest społeczeństwo. Formy powstawania instytucji to jedna z różnic pomiędzy instytucjami formalnymi i nieformalnymi, inną jest sposób ich egzekwowania i konsekwencje ich nieprzestrzegania (tab. 2)

Tabela 2. Wybrane różnice między instytucjami formalnymi i nieformalnymi

\begin{tabular}{|l|l|l|}
\hline \multicolumn{1}{|c|}{ Kryteria porównania } & \multicolumn{1}{|c|}{ Instytucje formalne } & \multicolumn{1}{c|}{ Instytucje nieformalne } \\
\hline $\begin{array}{l}\text { Rodzaj kary za niewy- } \\
\text { pełnienie nakazów }\end{array}$ & $\begin{array}{l}\text { Prawna: odpowiedzialność kry- } \\
\text { minalna i administracyjna }\end{array}$ & $\begin{array}{l}\text { Społeczna: ostracyzm, utrata dobrego } \\
\text { imienia }\end{array}$ \\
\hline $\begin{array}{l}\text { Źródło zachowania } \\
\text { norm }\end{array}$ & $\begin{array}{l}\text { Normy zapisane w kodeksach } \\
\text { prawnych lub innych sformalizo- } \\
\text { wanych dokumentach }\end{array}$ & Prawo ,niepisane” \\
\hline Dla kogo działają? & Dla wszystkich jednostek & $\begin{array}{l}\text { Działanie ograniczone warunkami } \\
\text { jednolitych grup społecznych albo kół } \\
\text { prywatnych znajomych }\end{array}$ \\
\hline $\begin{array}{l}\text { Transakcje i społeczną } \\
\text { przynależność uczestni- } \\
\text { ków umowy określa się } \\
\text { tylko miarą efektyw- } \\
\text { ności wpływu państwa } \\
\text { na proces specyfikacji i } \\
\text { ochrony praw własności }\end{array}$ & $\begin{array}{l}\text { Nie zależą od cech charaktery- } \\
\text { stycznych uczestników umowy } \\
\text { Zależą od stopnia efektywno- } \\
\text { specyfikacjoji i ochrony praw } \\
\text { własności. }\end{array}$ & $\begin{array}{l}\text { Minimalne w przypadku realizacji } \\
\text { umów granicach jednolitych grup } \\
\text { społecznych albo w kręgu znajomości } \\
\text { prywatnych. Maksymalne - w innych } \\
\text { przypadkach. }\end{array}$ \\
\hline
\end{tabular}

Źródło: [Tkaczyk 2007, s. 333].

Zarówno instytucje formalne, jak i nieformalne regulują i stanowią o relacjach między podmiotami rynku. Instytucje nie pozostają stałe, lecz ciągle ewoluują, zmieniając tym samym ład instytucjonalny. Łącznikiem między przeszłością a przyszłością są zatem instytucje. Formalne instytucje na przestrzeni czasu można zmienić w dosyć prosty sposób, poprzez np. zmianę przepisów prawa czy wprowadzenie nowych ustaw; nieformalne instytucje z kolei są głęboko zakorzenione w świadomości społeczeństwa, dlatego też potrzeba znacznie więcej czasu, aby je zmienić. 


\subsection{Przemiany instytucji systemu finansowego $w$ Polsce w okresie transformacji}

System finansowy definiowany jest jako „układ wzajemnie powiązanych instytucji finansowych, rynków finansowych oraz elementów infrastruktury systemu finansowego" [www.nbportal.pl]. Najważniejszymi jego funkcjami są funkcje:

- „monetarna (dostarcza podmiotom niefinansowym pieniądza i umożliwia jego obieg w gospodarce),

- kapitałowo-redystrybucyjna (umożliwia przepływ wolnych środków od tych podmiotów, które nimi dysponują, do tych, które ich potrzebują),

- kontrolna (sprawuje kontrolę nad strumieniami pieniężnymi, w szczególności nad środkami zainwestowanymi, wypożyczonymi i redystrybuowanymi w przeszłości)" [www.nbportal.pl].

Polskie prawo bankowe reguluje działalność instytucji finansowych i definiuje każdą z nich (,bank” zdefiniowany jest w art. 2 Prawo bankowe, ,instytucje finansowe” w art. 4 pkt 7, ,instytucje kredytowe” w art. 4 pkt 17, oraz ,przedsiębiorstwa pomocnicze usług bankowych" w art. 4 pkt 12). Zatem można powiedzieć, że w Polsce zasięg rynku finansowego wyznaczają banki, instytucje finansowe i instytucje kredytowe [Bączyk 2006]. System finansowy odgrywa w gospodarce ważną rolę związaną z transferem kapitału od podmiotów posiadających oszczędności do podmiotów, które go potrzebują w celu dalszego funkcjonowania i rozwoju.

Jednym z podmiotów rynku finansowego jest bank wchodzący w skład systemu finansowego, a traktowany jako organizacja. Instytucjami formalnymi, z ekonomicznego punktu widzenia, składającymi się na system finansowy w Polsce, jest ustawodawstwo regulujące relacje między podmiotami rynku; z kolei instytucją nieformalną jest zaufanie.

Transformacja systemowa w Polsce, która rozpoczęła się w roku 1989, doprowadziła do przemiany zarówno instytucji formalnych, jak i instytucji nieformalnych systemu finansowego.

Pierwszą zasadniczą zmianą było uchwalenie nowej ustawy Prawo bankowe [Ustawa z 31 stycznia 1989] oraz ustawy o Narodowym Banku Polskim (NBP) [Ustawa z 31 stycznia 1989]. Do najważniejszych zmian, jakie dokonały się po wprowadzeniu wyżej wymienionych ustaw, było:

- utworzenie dwuszczeblowego systemu bankowego wraz z bankiem centralnym, który pełnić miał funkcje nadzorcze oraz kształtować politykę pieniężną bez prowadzenia działalności operacyjnej; banki komercyjne realizować miały z kolei „funkcje zaliczane do działalności bankowej w sposób autonomiczny (w ramach norm prawnych i ustaleń banku centralnego), zgodnie z ideą samofinansowania" (por. [Lissowska 2008, s. 191]);

- uchylenie prawotwórczych kompetencji rządu w obrębie systemu bankowego; 
- uporządkowanie stosunków między systemem bankowym a Skarbem Państwa, poprzez likwidację mechanizmu automatycznego przyznawania kredytów na cele rządowe;

- rozszerzeniu katalogu czynności bankowych (System bankowy w Polsce w latach dziewięćdziesiątych [www.nbp.pl, s. 2]).

W dalszych latach dokonywały się kolejne przemiany instytucjonalne dostosowujące sektor bankowy do wymagań gospodarki rynkowej. Wprowadzone zostały następujące nowe reguły w postaci ustaw zwiększających stabilność sektora bankowego, m.in. wprowadzono:

- w roku 1993 ustawę o restrukturyzacji finansowej przedsiębiorstw i banków [Ustawa z 3 lutego 1993];

- w roku 1994 ustawę o restrukturyzacji banków spółdzielczych i Banku Gospodarki Żywnościowej [Ustawa z 24 czerwca 1994];

- w roku 1994 ustawę o Bankowym Funduszu Gwarancyjnym [Ustawa z 14 grudnia 1994];

- w roku 1995 ustawę o spółdzielczych kasach oszczędnościowo-kredytowych [Ustawa z 14 grudnia 1995].

Głównym problemem w okresie transformacji były tzw. złe kredyty. Przed rokiem 1989 wiele podmiotów otrzymywało kredyty na zasadach preferencyjnych, tylko po to, aby mógł być zrealizowany plan gospodarczy administracji państwowej. W nowych warunkach, po wprowadzeniu powyższych zmian, konieczne stało się „dokonanie zmiany instytucjonalnej poprzez uchylenie poprzednio obowiązujących preferencyjnych zasad w stosunku do już udzielonych kredytów" (por. [Lissowska 2008, s. 191]). Kolejnym problemem było to, iż prawo bankowe z 1989 roku nie regulowało w sposób precyzyjny nadzoru bankowego czy zasad prowadzenia operacji bankowych. Dopiero w roku 1997 wprowadzono w prawie bankowym odpowiednie regulacje, a trzy lata wcześniej - poprzez ustanowienie Bankowego Funduszu Gwarancyjnego, który miał zapewniać bezpieczeństwo środków powierzonych bankom oraz udzielać zwrotnej pomocy finansowej bankom mającym trudności w utrzymaniu płynności [Ustawa z 14 grudnia 1994].

W związku z tym, iż instytucje formalne nie mogą istnieć bez instytucji nieformalnych, wprowadzone zmiany instytucji formalnych wpłynęły na instytucje nieformalne i stały się nowymi uwarunkowaniami w rozwoju społecznym i gospodarczym (por. [Grabowska-Powaga, Jakubowska 2016]).

Przykładem instytucji nieformalnych jest poziom zaufania społeczeństwa do poszczególnych jednostek oraz do instytucji w danej społeczności. Jak pokazują badania, zaufanie Polaków do innych ludzi po roku 1989 utrzymuje się na dosyć niskim poziomie (tab. 3), ale można zauważyć, iż na przestrzeni lat obserwujemy jego wzrost. 
Tabela 3. Zaufanie Polaków do innych (w \%)

\begin{tabular}{|c|c|c|c|c|c|c|c|c|c|c|c|c|c|}
\hline 1992 & 1993 & 1994 & 1995 & 1997 & 1999 & 2002 & 2003 & 2005 & 2007 & 2009 & 2011 & 2013 & 2015 \\
\hline 10,3 & 9 & 8,4 & 8,4 & 10,3 & 12,4 & 13,8 & 10,5 & 10,5 & 11,5 & 13,4 & 13,4 & 12,2 & 15,2 \\
\hline
\end{tabular}

Źródło: [European Social Survey 2010; Diagnoza Społeczna 2014; 2015, s. 352].

Zaufanie społeczeństwa do banków jest odzwierciedleniem zaufania społeczeństwa do kształtujących je instytucji formalnych. Nie bez znaczenia na poziom zaufania w społeczeństwie miały przemiany instytucji formalnych w okresie transformacji po roku 1989 opisane powyżej.

Tabela 4. Ogólna opinia ludności o działających w Polsce bankach w latach 1994-2006 (w \%)

\begin{tabular}{|l|c|c|c|c|c|c|c|c|c|c|c|c|c|}
\hline \multicolumn{1}{|c|}{ Rok } & 1994 & 1995 & 1996 & 1997 & 1998 & 1999 & 2000 & 2001 & 2002 & 2003 & 2004 & 2005 & 2006 \\
\hline $\begin{array}{l}\text { Opinia } \\
\text { pozytywna }\end{array}$ & 25 & 34 & 53 & 56 & 65 & 69 & 69 & 65 & 59 & 60 & 66 & 62 & 69 \\
\hline $\begin{array}{l}\text { Opinia } \\
\text { negatywna }\end{array}$ & 36 & 33 & 24 & 17 & 15 & 15 & 15 & 20 & 25 & 20 & 21 & 23 & 23 \\
\hline
\end{tabular}

Źródło: opracowanie na podstawie [Kulińska-Sadłocha, G. Kotliński 2010, s. 154; Audyt bankowości detalicznej... 2007].

Jak pokazują dane w tab. 4르. Polacy w roku 1994 w 36\% mieli negatywne zdanie o bankach, czyli również o kształtujących je instytucjach formalnych (przypuszczać można, że nie darzyli zaufaniem tych instytucji). Jednak już rok później opinie negatywne i pozytywne były prawie na tym samym poziomie. W kolejnych latach zaobserwować można już znaczący wzrost pozytywnych opinii o bankach, czyli także o zmianach instytucji formalnych i wzroście zaufania do nich. Zmiany stanowiska społeczeństwa do banków w kolejnych latach można dopatrywać się we wprowadzanych transformacjach instytucji formalnych, takich jak np. wprowadzenie w roku 1994 ustawy o Bankowym Funduszu Gwarancyjnym. Ustawa ta gwarantowała klientom banków bezpieczeństwo powierzonych im środków finansowych, z kolei poczucie bezpieczeństwa przekładało się na wzrost poziomu zaufania do instytucji bankowych. W kolejnych latach zaufanie do instytucji bankowych znacząco wzrosło, przypuszczać można, iż było to efektem wprowadzania kolejnych zmian w zakresie instytucji formalnych kształtujących rynek usług finansowych.

\section{Zakończenie}

Reforma systemu bankowego w Polsce była jedną z pierwszych przemian, jakie nastąpiły w naszym kraju po roku 1989. Z uwagi na to, iż instytucje bankowe mu-

1 Instytut badania opinii publicznej Pentor rozpoczął badania dotyczące poziomu zaufania Polaków do banków w 1994 roku, dlatego też trudno jest wnioskować, jaki był poziom zaufania Polaków do banków przed rokiem 1994. 
siały dopasować się do nowych warunków gospodarki rynkowej, przemiany systemu bankowego były niezbędne. Konieczne było przeprowadzenie transformacji instytucji formalnych i nieformalnych w tym obszarze. Zmiany instytucji formalnych obserwować można było we wprowadzaniu nowych reguł gry w postaci zmiany przepisów prawnych czy ustanowienia całkowicie nowych, regulujących funkcjonowanie instytucji bankowych. Przeobrażenia te były niezbędne i konieczne do tego, aby wzmocnić zaufanie społeczne do instytucji bankowych i całego systemu bankowego, czyli także do instytucji nieformalnych.

\section{Literatura}

Audyt bankowości detalicznej 1994-2005, Audyt Bankowości detalicznej 2006, 2007, Pentor, http:// www.pentor.pl/48553.xml?doc_id=11278.

Bączyk M., 2006, Wprowadzenie, [w:] Prawo bankowe i inne teksty prawne - tekst jednolity, Wydawnictwo C.H. Beck, Warszawa.

Commons J.R., 1934, Institutional Economics. It's Place in Political Economy, Macmillan, New York.

Diagnoza Społeczna 2013, 2014, Warunki i jakość życia Polaków, red. J. Czapiński, T. Panek, Warszawa 2014.

Diagnoza Społeczna 2015, 2015, Warunki i jakość życia Polaków, red. J. Czapiński, T. Panek, Warszawa 2015.

European Social Survey, 2010, Polska dla lat 1992-2002, Polski Generalny Sondaż Społeczny dla lat 2003-2013 - Diagnoza Społeczna, ADS, Warszawa.

Grabowska-Powaga, A., Jakubowska, A., 2016, Institutions creating social capital in Poland after 1989 - selected aspects, pobrane z: www. eaepe.org.

Hodgson G.M., 2006, What are institutions?, Journal of Economics Issues, vol. XL, no. 1, s. 18.

Jakubowska A., Grabowska-Powaga A., 2016, Instytucje a aktywność gospodarcza podmiotów - wybrane aspekty, Zeszyty Naukowe Politechniki Śląskiej, Organizacja i Zarządzanie, z. 97, Wydawnictwo Politechniki Śląskiej, Gliwice.

Jütting J., 2013, Institutions and Development: A Critical Review, OECD Development Centre, Working Paper no 210, Paris, s. 11-14.

Kołodko G., 2004, Znaczenie instytucji i polityki dla szybkiego rozwoju gospodarczego, [w:] Noga A. (red.), 2004, Zmiany instytucjonalne w polskiej gospodarce rynkowej, Wydawnictwo PTE, Warszawa.

Kulińska-Sadłocha E., Kotliński G., 2010, Zaufanie jako element rozwoju nowego systemu bankowego w Polsce, [w:] Stabilizowanie sektora bankowego w okresie kryzysu, red. A. Janc, Zeszyty Naukowe nr 155, Wydawnictwo Uniwersytetu Ekonomicznego w Poznaniu, Poznań

Lissowska M., 2008, Instytucje gospodarki rynkowej w Polsce, Wydawnictwo C.H. Beck, Warszawa.

Noga A. (red.), 2004, Zmiany instytucjonalne w polskiej gospodarce rynkowej, Wydawnictwo PTE, Warszawa.

North D.C., 1990, Institutions, Institutional Change and Economic Perfomance, Cambridge University Press, New York.

North D.C., 1994, Economic Performance Through Time, The American Economic Review, vol. 84, no. 3 .

Spychalski G., 1999, Zarys historii myśli ekonomicznej, PWN, Warszawa-Łódź. 
Tkaczyk A., 2007, Zmiany instytucjonalne w gospodarce: Doświadczenia ukraińskie i polskie, [w:] Nierówności społeczne a wzrost gospodarczy. Gospodarka oparta na wiedzy, M.G. Woźniak (red.), z. 10, KTEiSM UR, Rzeszów.

Ustawa o Bankowym Funduszu Gwarancyjnym z dnia 14 grudnia 1994 roku.

Ustawa z dnia 3 lutego 1993, Dz.U. nr 18.

Ustawa z dnia 14 grudnia 1994., Dz.U. nr 4.

Ustawa z dnia 14 grudnia 1995, Dz.U. 1996, nr 1.

Ustawa z dnia 24 czerwca 1994, Dz.U. nr 80, poz. 369.

Ustawa z dnia 31 stycznia 1989 r. o Narodowym Banku Polskim, Dz.U.1989, nr 4, poz.22.

Ustawa z dnia 31 stycznia 1989 r. - prawo bankowe, Dz.U. 1989, nr 4, poz.21.

Veblen T., 2008, Teoria klasy próżniaczej, Warszawskie Wydawnictwo Literackie MUZA SA, Warszawa.

Wilkin J., 2016, Instytucjonalne i kulturowe podstawy gospodarowania. Humanistyczna perspektywa ekonomii, Wydawnictwo Naukowe Scholar, Warszawa.

Williamson O.E., 2000, The New Institutional Economics: Taking Stock, Looking Ahead, Journal of Economic Literature, vol. XXXVIII, nr 3, s. 597-598.

www.nbportal.pl/slownik/pozycje-slownika/system-finansowy (22.05.2017). 